\title{
Herbaceous Species Diversity in Kanawa Forest Reserve (KFR) in Gombe State, Nigeria
}

\author{
Abba Halima Mohammed", Sawa Fatima Binta Jahun², Gani Alhassan Mohammed², \\ Abdul Suleiman Dangana ${ }^{2}$
}

${ }^{1}$ Biology Unit, School of Basic and Remedial Studies, Gombe State University, Gombe, Nigeria

${ }^{2}$ Department of Biological Sceinces, Abubakar Tafawa Balewa University, Bauchi, Nigeria

Email address:

halimamohammedabba77@gmail.com (A. H. Mohammed), halimamohammedabba@yahoo.com (A. H. Mohammed)

\section{To cite this article:}

Abba Halima Mohammed, Sawa Fatima Binta Jahun, Gani Alhassan Mohammed, Abdul Suleiman Dangana. Herbaceous Species Diversity in Kanawa Forest Reserve (KFR) in Gombe State, Nigeria. American Journal of Agriculture and Forestry. Vol. 3, No. 4, 2015 , pp. 140-150. doi: 10.11648/j.ajaf.20150304.14

\begin{abstract}
The study was conducted between 2009 and 2011 in Kanawa Forest Reserve (KFR) in order to determine the impact of anthropogenic pressures and environmental changes of the herbaceous species. The project area was divided into six sites following the variety of land forms in the forest and three transects measuring $100 \mathrm{~m}$ were laid within each site. Point Centered Quarter (PCQ) sampling method was used. Data obtained were analyzed for relative density, relative frequency, and importance value index. A total of (35) species were identified in KFR out of which 16 species belonged to grasses within three families and 19 genera. The family Poaceae had the highest number, 10 species, the Cyperaceae had 5 species, while the Typhaceae had only 1. 19 species belonged to forbs within fourteen families and 16 genera. The families Asteraceae and Leguminosae: Fabaceae had 3 species each: Rubiaceae had 2 species each. Acanthaceae, Capparidaceae, Euphorbiaceae, Nyctaginaceae, Zygophyllaceae, Portulacaceae, Polygonaceae, Solanaceae, Onagraceae, Labiatae and Commelinaceae all had 1 species each. Simpson's index of diversity was 0.998 and Shannon-Wiener Index was 4.57. This condition indicates complex vegetation. Chi square and its related statistics showed significant positive associations between site I and IV, II and IV, V and VI. Only site I and IV, II and IV, V and VI were significantly negatively associated at $(\mathrm{P}<0.05)$. The species with the lowest importance value indices were:- Pennisetum pedicellatum, Polygonum senegalense, Vetiveria nigrinata, Zornia glochidiata. These plants therefore require more efforts on conservation.
\end{abstract}

Keywords: Herbaceous, Biodiversity, Kanawa Forest Reserve (KFR) and Inventory

\section{Introduction}

According to Hornby (2001), herbs are usually small tender plants, lacking of woody stems above ground. They occur in a wide variety of forms and leaf structures, including annuals, biennials and perennials, and broad-leaved plants (forbs) as well as the grasses. Herbaceous species also constitutes an important vegetative component of the environment due to its diverse ecological importance, including the maintaining of the structure and function of forests (Iwara et al, 2014). In particular they have the role of being an habitat for wild array of animals, the base for complex food web, stabilizing the soil, preventing soil erosion. Furthermore they have an economic relevance such as sources of fodder, food, fuel and medicines, aesthetic and cultural values for vast number of people throughout the world (Abdullahi, 2011). Some herbaceous species in KFR such as Euphorbia hirta, Zornia glochidiata, Mucuna prureins, Kyllinga tenuifolia, Cyperus sphacelatus, Acanthospernum hispidium, Physallis angulata, Portulaca oleraceae, Ludwigia hyssopifolia are used for medicinal purposes. Both human and animal ailments are treated through the use of these local vegetables. In most instances, these plant species are considered specific for a particular illness but they have occasionally mixed usages. Other species such as Zornia glochidiata, Chloris pilosa, Digitaria horizontallis, Mucuna prureins, Pennisetum pennicelatum, Commelina erecta, Eragrostis ciliaris are used for forage/ fodder. Vetivera nigrinata and Andropogan gayanus are also raw material for the production fuel. Typha domingensis is an invasive herb that has a strong and possibly expanding presence in the wetter habitats of the reserve. Herbaceous 
species however plays a major role in improving water penetration into soils and adding organic matter that improves moisture holding capacity and plant growth. It indeed plays important functions relating to productivity and environmental health by reducing the velocity of runoff (Department of Environment and resource management, 2010). Notwithstanding its small stature, herbaceous species has huge ecological significance of mediating carbon dynamics and energy flow and influencing the cycling rates of essential nutrients, including $\mathrm{N}, \mathrm{P}, \mathrm{K}$ and $\mathrm{Mg}$ (Gilliam, 2007). The herb community of tropical forests is very little known, with few studies addressing its structure quantitatively. Even with this scarce body of information, it is clear that the herbs are a rich group, comprising 14 to $40 \%$ of the species found in total species counts in tropical forests. This stratum remains an underappreciated aspect of forest ecosystems (Gilliam, 2007).The quantitative plant diversity inventories are the fundamental tool for conservation and management of tropical forests (Campbell 1994), but as far as KFR are concerned they are limited and quantitative inventories of understory species are still lacking. The documentation and classification of this unique and often neglected vegetation community may enable efforts to be made for biological conservation (Jennings et al., 2009: Ahmad and Ehsan, 2012).The problem is that due to over collection and climate change several species are fast disappearing.The herbaceous flora of KFR is one of the diverse among the savanna vegetation types of Northern Nigeria and this could mainly be due to climatic, edaphic and human impact. Although studies have been undertaken in other forest reserves in Nigeria, Kanawa Forest Reserve (KFR) (since establishment between 1940 and 1945 has not received such scientific attention. It therefore became imperative to take stock of the status of the herbaceous vegetation of Kanawa forest with a view to deriving appropriate conservation measures. The aim of the study was to obtain an inventory of the herb species of (KFR), in order to determine their relative importance and diversity.

\section{Materials and Methods}

\subsection{The Study Area}
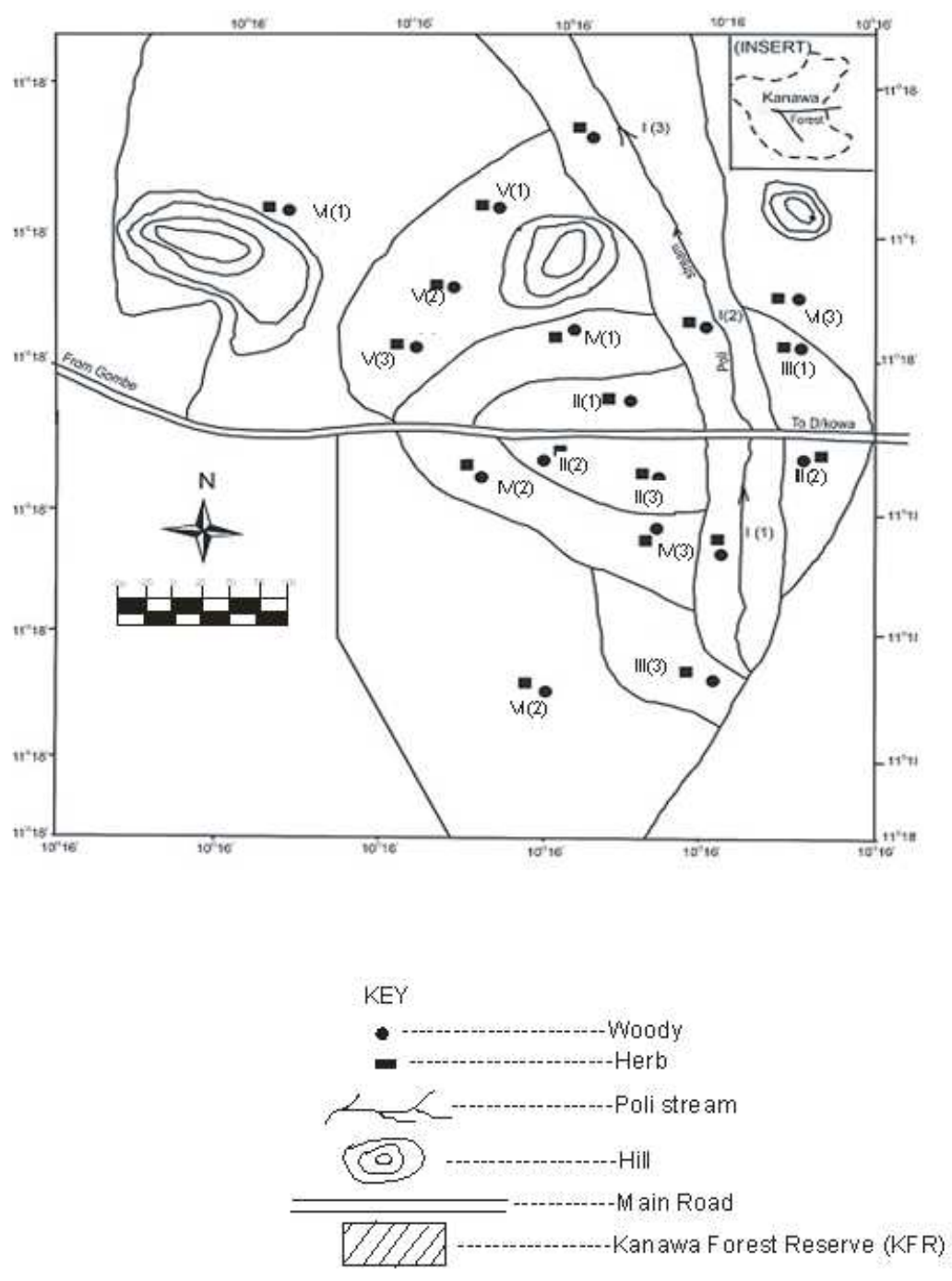

Ste I-

Figure 1. Map showing the study sites and location of sampling points in Kanawa Forest Reserve. 
KFR is located in the North Eastern part of Nigeria in Yamaltu/Deba Local Government Area of Gombe State and it lies in the Southern part of the Sudan Savanna between latitude 10016 'N and 10o 18' 30"N longitude 11o 18'10" E. and 11o 22' 09" E . and at an altitude of 336-390 mamsl. The size of the forest was 41 hectares (Gombe Native Authority, 1945) and it was gazetted as a forest reserve in 1953. At present the Kanawa Forest Reserve is presently 53 hectares due to the acquisition of surrounding farmlands by Gombe State Government.

The terrain is generally undulating, with dendritic shallow V-shaped drainage (Samaila, 2011). The soil types were loamy sand, sandy and sandy loam types (Abba et al., 2013)

The climate is characterized by two distinct seasons: The rainy season one that lasts from April through October and the dry ones that goes from November to March. The rainfall pattern is bimodal with an annual total which ranges from $658-923 \mathrm{~mm}$. The mean annual temperature ranges from 32.2 to $32.80 \mathrm{C}$. Six sites were used for vegetation sampling following the selecting criteria of topography, soil, and vegetation types. The vegetation of (KFR) is a mosaic made up of dense Sudan savanna vegetation especially around the hilly part of the reserve (Site VI). Marshy(Site IV), riparian (Site I), lowland rainforest vegetation near the Poli stream (Site II) grassland with tall grasses (Site III) and thorn vegetation in the drier part of the forest (Site V). In each site, three sampling locations were identified (Fig 1).

\subsection{Sampling Procedure and Methodology}

The point centred quarter (PCQ) method was employed (Cottam and Curtis 1956; Dix, 1971; Abdullahi, 2010). Three transects $(1,2,3)$ of $100 \mathrm{~m}$ long each were laid per site. There were 10 sampling points per transect giving a total of 30 sampling points. On each sampling point four quarters were demarcated and the nearest herb plant in terms of distance from the point to the center of the herb plant. Readings were recorded in meters within each quarter. This was done for all the sampling points on each transect.

\subsection{Data Collection and Analysis}

In each sampling point all nearest living herb species encountered were listed. In each site, all nearest living herb plant were measured with measuring tape in each quarter and recorded. Species encountered were identified on site with the help of field guides and floras and texts (Blair, 1976; Lowe and Stanfeild,1974; Akobundu and Agyakwa, 1998). Also morphological characteristics involving fruits, flowers, leaves and stem, bark and sap were used for identification. The specimens were collected and compared with herbarium specimens of the Biological Sciences Programme, Abubakar Tafawa Balewa University, Bauchi, Nigeria. Nomenclature of the species follows Hutchinson and Dalzeil (1972).

Data obtained were quantitatively analyzed for Relative density (RD), Relative frequency (RF) following Curtis (1959), and the relative values were summed up to obtain Importance Value index (IVI) (Misra,1968, Dallmier,1992; Sabogal,1992; Abdullahi, 2010). The formulae used to calculate RD, RF and (IVI) are as follows:-

$\mathrm{RD}=$ (number of individuals of a species)/ (total number of individuals of all species) $x 100$.

$\mathrm{RF}=$ (frequency of one species)/ (sum of all frequencies) $\mathrm{x} 100$

$\mathrm{IVI}=\operatorname{sum}$ of $(\mathrm{RF}+\mathrm{RD}) / 2$

The value of IV1 may range from 0 to $200 \%$. Dividing it by 2 will result in a figure that ranges from 0 to $100 \%$. This value is referred to as the importance percentage.

Species diversity was calculated using Simpson's index (Simpson, 1949) with this formula:

$\mathrm{D}=[\mathrm{N}(\mathrm{N}-1)] /$ [summation of $\mathrm{n}(\mathrm{n}-1)]$, where $\mathrm{D}$ is the diversity index, $\mathrm{N}$ is the total number of individuals of all plant species found, $\mathrm{n}$ is the number of individuals of a particular species.

Species diversity index was also calculated using the Shannon-Weiner index (Shannon, 1948)

$$
H^{\prime}=-\sum_{i=1}^{R} \mathrm{Pi} \text { in } \mathrm{Pi}
$$

Where $H^{\prime}$ is the = Shannon - Weiner diversity index $\mathrm{Pi}=$ is the proportion of each species in the sample.

$\mathrm{R}=$ represents the total number of species

Chi-Square analysis was calculated using the following formulae:

$\chi 2=n(a d-b c) 2 /(a+b)(c+d)(a+c)(b+d)$, while the correlation coefficient was obtained as follows: i (Causton, 1988)

$$
\begin{aligned}
& \mathrm{r}=\mathrm{ad}-\mathrm{bc} / \sqrt{ }\{(\mathrm{a}+\mathrm{b})(\mathrm{c}+\mathrm{d})(\mathrm{a}+\mathrm{c})(\mathrm{b}+\mathrm{d})\}-\mathrm{ii} \\
& \text { From the above equations; } \\
& \mathrm{n}=\text { number of species in the data set } \\
& \mathrm{a}=\text { number of species common to sites A and B } \\
& \mathrm{b}=\text { number of species present in site } \mathrm{A} \text { but not } \mathrm{B} \\
& \mathrm{c}=\text { number of species present in site } \mathrm{B} \text { but not } \mathrm{A} \\
& \mathrm{d}=\text { number of species absent in site A and B } \\
& \chi=\text { chi-square } \\
& \mathrm{r}=\text { correlation coefficient }
\end{aligned}
$$

\section{Results and Discussion}

A total of (35) species of herbs were identified out of which 16 species belonged to grasses within 3 families and 19 genera and 19 species belonged to forbs within 14 families and 16 genera within an area of 53 hectares, of which 10 species were encountered in the riparian (site I), 8 in lowland rainforest vegetation near Poli stream (Site II), 9 in grassland with tall grasses (Site III), 8 in Marshy (Site IV), 7 in thorn vegetation in the drier part of the forest (Site $\mathrm{V})$, and 13 in the dense Sudan savanna vegetation especially around the hilly part of the reserve (Site VI) respectively. A total of 14 families were recorded for forbs 
(Table 1). In the study area, the families Asteraceae and Leguminosae: Fabaceae had 3 species each: Rubiaceae had 2 species each. Acanthaceae, Capparidaceae, Euphorbiaceae, Nyctaginaceae, Zygophyllaceae, Portulacaceae, Polygonaceae, Solanaceae, Onagraceae, Labiatae and Commelinaceae all had 1 species each. A total of three families were recorded for grasses (Table 2). The family Poaceae had the highest number, 10 species. The family Cyperaceae had 5 species; Typhaceae had only 1 species.

From the above results, the families that had the most common herb species were Poaceae and Cyperaceae. The Poaceae family is one of the most widely distributed and abundant groups and important family of the earth's flora. Their success results from their tolerance of grazing herbivores and fire, their varied means of reproduction, and their versatility in photosynthesis. These families were also known to be native species in most savannah-woodland mosaics in Africa and more typical of the Sudano-Sahelian zone. A similar study was carried out by Atiku and Bello (2011) at Wassaniya Forest Reserve of Sokoto State (Nigeria), using the point centered quarter method. Another investigation was carried out in Yankari Game Reserve (YGR), in the Savanna-Woodlands of Northern Nigeria by Abdullahi (2010). The number obtained in the present study was higher than that of Wassaniya Forest Reserve probably because of the size, location, soil composition, soil types and climatic factors which gave rise to a higher number of species. It was however lower than that of Yankari Game Reserve, because of the statute of Yankari as a game reserve and the moist-warm climate, geological and topographic nature of the area.

Table 3, reveals the relative density of herbs. The highest value in the reserve was Typha domingensis (37.50\%) revealing that it was the most abundant species in the forest because Typha species were often among the first wetland plants to colonize areas of newly exposed wet mud, with their abundant wind dispersed seeds which provides a greater reproductive capacity. Buried seeds could survive in the soil for long periods of time and they germinate best with sunlight and fluctuating temperatures. The plants also spread by rhizomes, forming large, interconnected stands with extensive root systems which provides a rapid growth and makes them invasive and proliferative.

The lowest value was recorded on Polygonum senegalense $(2.50 \%)$, probably due because of the continous use for removal of ecto parasites from livestock and also orally administered to cattle for managing unstated diseases. The herb species Hyptis suaveolens had the highest relative densities $(15.00 \%)$ at site I and II probably because Hyptis shows strategy for better survival and establishment. It exhibit vigorous growth in the forest. Fenner (1985) reported that a number of vegetative characters are helpful in the heavy proliferation of Hyptis such as small seed size, prolific seed production forming persistent propagule bank within short period, seed dimorphism, autogamic and allogamic mode of reproduction, good proliferation from the perrenating rootstock, probable allele chemicals and presence of essential oil conferring resistance to it against variety of pathogens. Factors favoring the growth of Hyptis is the small seed size, which easily penetrates into cracks or small openings in the soil. Reduction in size along with large number of seeds has also been associated with predator avoidance as reported by Fenner (1985). Seed dimorphism in Hyptis is helpful in its germination across a range of temperature conferring year round seed germination.

Typha domingensis had the highest relative densities $(15.00 \%)$ at site I and Kyllinga tenuifolia at site IV. Those species were high because of their extensive root system and they often exclude other plants with their dense canopy. The species Vetiveria nigritana had the lowest relative density $(4.17 \%)$ at site VI, because the roots have been used continuously for their fragrance and are woven into fragrant-smelling mats and fans by the locals living around the reserve. Lastly, Vetiveria nigritana is beneficial to poor farmers because it provides traditional cost effective ways to fight infections and diseases. The plant also contains active ingredients used in traditional medicine and as botanical pesticide.

Euphorbia hirta $(8.16 \mathrm{~m} 2 /$ ha) had the highest absolute density in the reserve, hence the most densely populated species. This was because it grows on all type of soils and it reproduces by seeds up to 3,000 seeds per plant. The plant is dispersed in an active way by projection or in a passive way by the activity of ants. Herbivours also play a key role in long distance dispersal of propagules (Milton and Dean, 2001) enhancing local colonization processes and plant diversity (Olff and Ritchie, 1998). The lowest value was recorded on Zornia glochidiata $(0.600 \mathrm{~m} 2 / \mathrm{ha})$, because the species is considered a good fodder plant for animals and leaves are sources of food and medicine. Chloris pilosa and Chamaecrista mimosoides had the highest absolute density ( $5.64 \mathrm{~m} 2 / \mathrm{ha}$ ) in site V. The two species belongs to Poaceae and Leguminosae: Fabaceae family which is known to be propagated by seeds. The lowest absolute density $(0.56 \mathrm{~m} 2 /$ ha) was recorded on Digitaria horizontalis at site I, because it was highly grazed upon as sources of fodder by animals. This study was consistent with the findings of (Abdullahi et al., 2009; Atiku and Bello, 2011) at YGR, Bauchi and Wassaniya Forest Reserve, Sokoto State, Nigeria.

The species with the highest absolute density in the reserve was Mucuna pruriens (46.36 $\mathrm{m} 2 / \mathrm{ha}$ ), hence the most densely populated. This shows that this herb had the highest number of species per unit area in the reserve. This high number could be because it was rapidly dispersed by seeds and the associated processes of germination, seedling establishment and survival were rapid. This finding was consistent with that of (Harper's, 1977).

Achyranthes aspera ( $8.54 \mathrm{~m} 2 / \mathrm{ha})$ was the species with the least number in the forest. It is highly sought for by humans as sources of food and medicine. Abrus precatorius, Ipomoea asarifolia, Luffa cylindrica and Mucuna pruriens had the highest absolute density in site 1 while the lowest values $(3.13 \%)$ was recorded on Combretum racemosum 
and Abrus precatorius. Mucuna pruriens (22.50) had the highest relative densities at site III while the lowest value was recorded on Achyranthes aspera (7.50).

Relative density was high because site III contains loamy sand, minimum amounts of moisture content, high organic matter content, total nitrogen and available phosphorus, with high amounts of exchangeable bases.

The relative frequency of herbs for KFR is presented in Table 4. Kyllinga tenuifolia and Cyperus sphacelatus had the highest grass frequency $(80 \%)$ in the reserve hence the most frequent grass species. The high frequency could probably be because of the presence of seeds that could easily be dispersed together with their rapid regeneration abilities. The lowest frequency in the reserve was recorded on Acanthospermum hispidium, Fimbristylis ferruginea, Fimbristylis meliacea, Pennisetum pedicillatum, Physalis angulata, Polygonum senegalense, Vetivera nigrinata, Zornia glochidiata. This could be because they were highly grazed upon by animals. The herb species Commelina erecta and Hyptis suaveolens had the highest frequencies at site II and Kyllinga tenuifolia had the highest frequency at site IV. The species Digitaria horizontalis, Ludwigia hyssopifolia, Physalis angulata, Tridax procumbens, Chloris pilosa had the lowest frequencies at site I. Chloris pilosa,Vernonia cineria, Portulaca oleraceae, Euphorbia hirta had the lowest frequencies at site II. Digitaria horizontalis, Kyllinga tenuifolia, Fimbristylis ferruginea, Fimbristylis meliaceae, Vetiveria nigritana, Eragrostis ciliaris, Eragrostis tremula, and Spermacose viticilata had lowest frequencies at site III. Tribulus terrestris had lowest frequencies at site IV. Euphorbia hirta, Tridax procumbens, Commelina erecta, Polygonum senegalense, Boerhavia diffusa, Cenchrus biflorus, Pennisetum pedicillata, Alysicarpus vaginalis had lowest frequencies at site V. Commelina erecta, Eragrostis tremula, Acanthospermum hispidium, Dactyloctenium aegyptiaca, Boerhavia diffusa, Cenchrus biflorus, Alysicarpus vaginalis, Zornia glochidata had the lowest frequencies at site VI. These low values could be due to human impact and their importance as sources of medicine, forage /fodder and food.

Cyperus sphacelatus and Kyllinga tenuifolia had the highest relative frequencies $(41.91 \%)$ in the reserve. This shows that the species had random distributions because the environmental conditions and resources were consistent and their modes of dispersal are sporadic. The lowest relative frequencies $(5.26 \%)$ were recorded on Polygonum senegalense. Euphorbia hirta, Hyptis suaveolens and Typha domingensis had highest relative frequencies at site I. Cyperus sphacelatus (17.65\%) had the highest relative frequency at site III. Vernonia cineria, Portulaca oleracea and Euphorbia hirta had lowest relative frequencies of $(4.17 \%)$ at site II. All this showed clumped distribution of species mainly because water only reaches the surface of the terrain in specific places and there is just enough to support their growth. This study was also in line with the works of (Abdullahi and Sanusi, 2006) and of Atiku and Bello (2011) who studied herbaceous species in Yankari game reserve, Bauchi State and Wasaniya Forest Reserve, Sokoto State, Nigeria.

From Table 5, the herb species with the highest Importance Value Index (IVI) in the whole forest reserve was Typha domingensis (43.81\%).The herb species Scleria verrucosa $(3.63 \%)$ had the lowest IVI in the reserve. The herb species Typha domingensis had the highest IVI of $(15.83 \%)$ at site I while the lowest was recorded for Scleria verrucosa $(3.63 \%)$ at site $\mathrm{V}$. The importance value, or the importance percentage, gives an overall estimate of the influence of importance of a plant species in the community.

The IVI is imperative at comparing the ecological significance of species and it indicates the extent of dominance of a species in the structure of a vegetation stand (Curtish and McIntosh, 1951; Rosenzweig, 1995: Abdullahi, 2010). IVI is also a reasonable measure to assess the overall significance of a species since it takes into account several properties of the species in the vegetation. The IVI was calculated as per Curtis and McIntosh (1951). The importance value indices IVI of the herbaceous species were generally low in the study area. The low IVI values could be due to different species with few individuals represented in each herbaceous species. This is consistent with the works of (Abdullahi, 2010). All these species were characteristic of Sudan Savanna vegetation types. The grasses were shorter than in the Guinea Savanna zones, and they had different characters. Most of the grasses were annuals because of drought-stress in the long dry period. A number of perennials grow vigorously too (Broekhuyse and Allen, 1984; Vierich and Stoop, 1990).

The results of Simpson's index of diversity (1-D) was (0.998), while Shannon- Weiner index of Diversity for the study area was (4.57) for the herb species. The values were high indicating a more complex and healthy community with greater variety of species allowing for more species interactions. This will ensure greater system stability, and indicating good environmental conditions. The high diversity could also be due to the high fertility related parameters and high moisture contents in some sites. It could also be due to the position of Kanawa Forest as a forest reserve.

A similar study was carried out by Abdullahi (2010) where he reported Simpson's index of diversity for herbs in Yankari National Park as (0.998). Richard et al., (2011) also reported Simpson's index of diversity as (0.957) for the Miombo woodland of Bereku Forest Reserve, in Tanzania. These values were higher than those of the present study due to size and higher enforcement of protection laws.

The Shannon-Wiener Index of diversity (H') was reported by Richard et al., (2011) to be 4.27 for the Miombo Woodlands of Bereku Forest Reserve and 2.76 in Khadimnagar National Park of Bangladesh as reported by Sobuj and Rahman (2011). The value of 4.27 is lower than the 4.57 obtained in the present study. The higher value observed in this study may be due to riparian vegetation found along the Poli stream that transverse part of the KFR along with its concomitant high fertility and variation in the 
ecotypes within the KFR.

The results of the association, similarity and correlation between site (Table 6) revealed that site III and VI had the highest association values (10.7905), while the lowest value (0.064815) was recorded in site I and II. Three positive associations at site I and IV, II and IV, V and VI. Only site I and IV, II and IV, V and VI were significantly negatively associated at $(\mathrm{P}<0.05)$. Sites I and III (23.58), had higher sum of chi-square (Sx). The Sx (sum of chi-square) and $\mathrm{Sr}$ (sum of correlation coefficient) values were similarly less than the total number of species in the data set (35) and $>$ greater than 1(one) except for three positive relationships depicting weak relationships and heterogeneity of the flora of KFR. According to Kumar et al., (2006) species distribution in areas with high diversity is always heterogeneous.

Table 1. Families and species of forbs identified at Kanawa Forest Reserve (KFR), Gombe State, Nigeria during 2010-2011.

\begin{tabular}{lll}
\hline S/No & Family & Species \\
\hline 1 & Acanthaceae & Nelsonia canescens (Lam) Sprengel \\
& & Acanthospermum hispidum DC \\
2 & Asteraceae & Tridax procumbens L. \\
& & Vernonia cineria Schreb \\
3 & Capparidaceae & Cleome viscosa L. \\
4 & Commelinaceae & Commelina erecta L \\
5 & Euphorbiaceae & Euphorbia hirta L. \\
& & Alysicarpus vaginalis (L.) DC \\
6 & Leguminosae: Fabaceae & Zornia glochidata Rehb ex DC \\
& & Chamaecrista rotundifolia (Pers.) \\
7 & Labiatae & Hyptis suaveolens L. \\
8 & Nyctaginaceae & Boerhavia diffusa L. \\
9 & Zygophyllaceae & Tribulus terrestris L. \\
10 & Onagraceae & Ludwigia hyssopifolia (G.Don) Exell \\
11 & Portulacaceae & Portulaca oleraceae L. \\
12 & Polygonaceae & Polygonum senegalense Meisn Senegalensis (Meisn) sojak \\
13 & Rubiaceae & Spermacose verticillata (L.) \\
14 & Solanaceae & Oldenlandia corymbosa L. \\
\hline
\end{tabular}

Table 2. Families and species of grasses identified at Kanawa Forest Reserve (KFR), Gombe State, Nigeria during 2010-11.

\begin{tabular}{lll}
\hline S/No $\quad$ Family & Species \\
\hline & Cyperus sphacelatus Rottb \\
& Fimbristylis ferruginea (L.) \\
& Fimbristylis meliaceae Vahl \\
& Kyllinga tenuifolia Steaud \\
& Scleria verrucosa Willd \\
& Andropogan gayanus Kunth \\
& Cenchrus biflorus Roxb \\
& Chloris pilosa Shumach \\
& Dactyloctenium aegyptium Linn P.Beauv \\
& Digitaria gayana (Kunth) Stapf ex A.Chev \\
& Digitaria horizontalis Willd \\
& Eragrostis ciliaris (L) R.Br \\
& Eragrostis tremula Hochst ex Steaud \\
& Pennisetum pedicillatum Trin \\
& Vetiveria nigrinata (Benth) Sap \\
& Typha domingensis (Pers) Steaud \\
&
\end{tabular}


Table 3. Relative and absolute density of herbs identified at Kanawa Forest Reserve (KFR), Gombe State, Nigeria.

\begin{tabular}{|c|c|c|c|c|c|c|c|c|c|c|c|c|c|c|c|}
\hline \multirow[b]{3}{*}{ S/No } & \multicolumn{8}{|c|}{ Absolute density (m2/ha) } & \multicolumn{7}{|c|}{ Relative density ( \%) } \\
\hline & & & & Site & & & & & & & & te & & & \\
\hline & Species & I & II & III & IV & $\mathrm{V}$ & VI & TOTAL & I & II & III & IV & $\mathrm{V}$ & VI & TOTAL \\
\hline 1 & $\begin{array}{l}\text { Acanthospermum } \\
\text { hispidium }\end{array}$ & & & & & & 1.00 & 1.00 & & & & & & 8.33 & 8.33 \\
\hline 2 & $\begin{array}{l}\text { Alysicarpus } \\
\text { vaginalis }\end{array}$ & & & & & 2.60 & 1.00 & 3.60 & & & & & 5.00 & 8.33 & 13.33 \\
\hline 3 & $\begin{array}{l}\text { Andropogan } \\
\text { gayanus }\end{array}$ & & & & & 3.04 & 0.90 & 3.94 & & & & & 5.83 & 7.50 & 13.33 \\
\hline 4 & Boerhavia diffusa & & & & & 3.47 & 0.90 & 4.37 & & & & & 6.67 & 7.50 & 14.17 \\
\hline 5 & Cenchrus biflorus & & & & & 1.30 & 1.20 & 2.50 & & & & & 10.00 & 10.00 & 20.00 \\
\hline 6 & $\begin{array}{l}\text { Chamaecrista } \\
\text { rotundifolia }\end{array}$ & & & & & 5.64 & 1.00 & 6.64 & & & & & 10.83 & 8.33 & 19.16 \\
\hline 7 & Chloris pilosa & 0.72 & 1.51 & & & 5.64 & & 7.87 & 8.33 & 7.50 & & & 10.83 & & 26.66 \\
\hline 8 & Cleome viscosa & & & & 3.08 & & & 3.08 & & & & 12.50 & & & 12.50 \\
\hline 9 & Commelina erecta & & 2.18 & & & 3.90 & 1.00 & 7.08 & & 10.83 & & & 7.50 & 8.33 & 26.66 \\
\hline 10 & $\begin{array}{l}\text { Cyperus } \\
\text { sphacelatus }\end{array}$ & & 1.68 & 2.22 & 3.08 & & & 6.98 & & 8.33 & 11.67 & 12.50 & & & 32.50 \\
\hline 11 & $\begin{array}{l}\text { Dactyloctenium } \\
\text { aegyptium }\end{array}$ & & & & & 4.34 & 0.90 & 5.24 & & & & & 8.33 & 7.50 & 15.83 \\
\hline 12 & Digitaria gayana & & & & 2.46 & & & 2.46 & & & & 10.00 & & & 10.00 \\
\hline 13 & $\begin{array}{l}\text { Digitaria } \\
\text { horizontalis }\end{array}$ & 0.55 & & 1.55 & & & & 2.10 & 5.00 & & 8.33 & & & & 13.33 \\
\hline 14 & Eragrostis ciliaris & & & 1.58 & & & 1.30 & 2.88 & & & 8.33 & & & 10.83 & 19.16 \\
\hline 15 & Eragrostis tremula & & & 1.58 & & & 1.00 & 2.58 & & & 8.33 & & & 8.33 & 16.66 \\
\hline 16 & Euphorbia hirta & 1.38 & 2.01 & & & 4.77 & & 8.16 & 12.50 & 10.00 & & & 9.68 & & 32.18 \\
\hline 17 & $\begin{array}{l}\text { Fimbristylis } \\
\text { ferruginea }\end{array}$ & & & 1.58 & & & & 1.58 & & & 8.33 & & & & 8.33 \\
\hline 18 & $\begin{array}{l}\text { Fimbristylis } \\
\text { meliacea }\end{array}$ & & & 1.58 & & & & 1.58 & & & 8.33 & & & & 8.33 \\
\hline 19 & Hyptis suaveolens & 1.7 & 3.02 & & & & & 4.73 & 15.00 & 15.00 & & & & & 30.00 \\
\hline 20 & Kyllinga tenuifolia & & 1.68 & 1.58 & 3.69 & & & 6.95 & & 8.34 & 8.34 & 15.00 & & & 31.66 \\
\hline 21 & $\begin{array}{l}\text { Nelsonia } \\
\text { canescens }\end{array}$ & & & & & 5.64 & & 5.64 & & & & & 10.33 & & 10.33 \\
\hline 22 & $\begin{array}{l}\text { Ludwigia } \\
\text { hyssopifolia }\end{array}$ & 0.92 & & 1.90 & & & & 2.82 & 8.33 & & 10.00 & & & & 18.33 \\
\hline 23 & $\begin{array}{l}\text { Oldenlandia } \\
\text { corymbosa }\end{array}$ & 1.01 & & & & & & 1.01 & 9.17 & & & & & & 9.17 \\
\hline 24 & $\begin{array}{l}\text { Pennisetum } \\
\text { pedicellatum }\end{array}$ & & & & & 5.20 & & 5.20 & & & & & 3.33 & & 3.33 \\
\hline 25 & Physalis angulata & 0.72 & & & & & & 0.72 & 8.33 & & & & & & 8.33 \\
\hline 26 & $\begin{array}{l}\text { Portulaca } \\
\text { oleraceae }\end{array}$ & & 1.51 & & 3.08 & & & 4.59 & & 7.50 & & 12.50 & & & 20.00 \\
\hline 27 & $\begin{array}{l}\text { Polygonum } \\
\text { senegalense }\end{array}$ & & & & & 1.30 & & 1.30 & & & & & 2.50 & & 2.50 \\
\hline 28 & Scleria verrucosa & & & 1.90 & & & & 1.90 & & & 10.00 & & & & 10.00 \\
\hline 29 & $\begin{array}{l}\text { Spermacose } \\
\text { verticillata }\end{array}$ & & & 0.95 & & & 1.23 & 2.18 & & & 5.00 & & & 10.00 & 15.00 \\
\hline 30 & Tribulus terrestris & 1.10 & & & 2.46 & & & 3.56 & 10.00 & & & 15.00 & & & 15.00 \\
\hline 31 & Tridax procumbens & 0.72 & 2.51 & & & 4.77 & & 8.00 & 8.34 & 12.00 & & & 9.17 & & 29.51 \\
\hline 32 & Typha domingensis & 1.65 & 1.51 & & 3.69 & & & 6.85 & 15.00 & 12.50 & & 10.00 & & & 37.50 \\
\hline 33 & Vernonia cineria & & 2.51 & 1.74 & 3.08 & & & 7.33 & & 12.50 & 9.17 & 12.50 & & & 34.17 \\
\hline 34 & Vetiveria nigrinata & & & 0.79 & & & & 0.79 & & & 4.17 & & & & 4.17 \\
\hline 35 & Zornia glochidiata & & & & & & 0.60 & 0.60 & & & & & & 5.02 & 5.02 \\
\hline
\end{tabular}


Table 4. Frequency, relative frequency of herbs identified at Kanawa Forest Reserve (KFR), Gombe State, Nigeria.

\begin{tabular}{|c|c|c|c|c|c|c|c|c|c|c|c|c|c|c|c|}
\hline \multicolumn{9}{|c|}{ Frequency $(\%)$} & \multicolumn{7}{|c|}{ Relative frequency ( \%) } \\
\hline & & $\mathbf{S i}$ & & & & & & & & & & Site & & & \\
\hline S/No & Species & 1 & 11 & 111 & $1 \mathrm{~V}$ & $\mathrm{~V}$ & V1 & TOTAL & 1 & 11 & 111 & $1 \mathrm{~V}$ & $\mathrm{~V}$ & V1 & $\begin{array}{l}\text { TOTA } \\
\text { L }\end{array}$ \\
\hline 1 & Acanthospermum hispidium & & & & & & 10 & 10 & & & & & & 6.67 & 6.67 \\
\hline 2 & Alysicarpus vaginalis & & & & & 10 & 10 & 20 & & & & & 5.27 & 6.67 & 11.94 \\
\hline 3 & Andropogan gayanus & & & & & 20 & 20 & 40 & & & & & 10.53 & 13.3 & 23.86 \\
\hline 4 & Boerhavia diffusa & & & & & 10 & 10 & 20 & & & & & 5.26 & 667 & 11.93 \\
\hline 5 & Cenchrus biflorus & & & & & 10 & 10 & 20 & & & & & 5.26 & 6.67 & 11.93 \\
\hline 6 & Chamaecrista rotundifolia & & & & & 20 & 10 & 30 & & & & & 10.53 & 6.67 & 17.20 \\
\hline 7 & Chloris pilosa & 10 & 10 & & & 20 & & 40 & 5.56 & 4.17 & & & 10.53 & & 20.26 \\
\hline 8 & Cleome viscosa & & & & 20 & 10 & & 30 & & & & 11.76 & & & 11.76 \\
\hline 9 & Commelina erecta & & 40 & & & 10 & 10 & 60 & & 16.67 & & & 5.26 & 6.67 & 28.60 \\
\hline 10 & Cyperus sphacelatus & & 30 & 30 & 20 & & & 80 & & 12.50 & 17.65 & 11.76 & & & 41.91 \\
\hline 11 & Dactyloctenium aegyptium & & & & & 30 & 10 & 40 & & & & & 15.79 & 6.67 & 22.46 \\
\hline 12 & Digitaria gayana & & & & 20 & & & 20 & & & & 11.76 & & & 11.76 \\
\hline 13 & Digitaria horizontalis & 10 & & 10 & & & & 20 & 5.56 & & 5.88 & & & & 11.44 \\
\hline 14 & Eragrostis ciliaris & & & 10 & & & 20 & 30 & & & 5.88 & & & 13.3 & 18.86 \\
\hline 15 & Eragrostis tremula & & & 10 & & & 10 & 20 & & & 5.88 & & & 6.67 & 12.55 \\
\hline 16 & Euphorbia hirta & 30 & 10 & & & 10 & & 50 & 16.67 & 4.17 & & & 5.26 & & 26.10 \\
\hline 17 & Fimbristylis ferruginea & & & 10 & & & & 10 & & & 5.88 & & & & 5.88 \\
\hline 18 & Fimbristylis meliacea & & & 10 & & & & 10 & & & 5.88 & & & & 5.88 \\
\hline 19 & Hyptis suaveolens & 30 & 40 & & & & & 70 & 16.64 & 16.65 & & & & & 33.29 \\
\hline 20 & Kyllinga tenuifolia & & 30 & 10 & 40 & & & 80 & & 12.50 & 5.88 & 23.53 & & & 41.91 \\
\hline 21 & Nelsonia canescens & & & & & 20 & & 20 & & & & & 10.53 & & 10.53 \\
\hline 22 & Ludwigia hyssopifolia & 10 & & 20 & & & & 30 & 5.56 & & 11.76 & & & & 17.32 \\
\hline 23 & Oldenlandia corymbosa & 20 & & & & & & 20 & 11.11 & & & & & & 11.11 \\
\hline 24 & Pennisetum pedicellatum & & & & & 10 & & 10 & & & & & 5.26 & & 5.26 \\
\hline 25 & Physalis angulata & 10 & & & & & & 10 & 5.56 & & & & & & 5.56 \\
\hline 26 & Polygonum senegalense & & & & & 10 & & 10 & & & & & 5.26 & & 5.26 \\
\hline 27 & Portulaca oleraceae & & 10 & & 20 & & & 30 & & 4.17 & & 11.76 & & & 15.93 \\
\hline 28 & Scleria verrucosa & & & 20 & & & & 20 & & & 11.76 & & & & 11.76 \\
\hline 29 & Spermacose verticillata & & & 10 & & & 20 & 30 & & & 5.88 & & & 13.3 & 19.21 \\
\hline 30 & Typha domingensis & 30 & 20 & & 20 & & & 70 & 16.67 & 8.33 & & 11.76 & & & 36.76 \\
\hline 31 & Tribulus terrestris & 20 & & & 10 & & & 30 & 11.11 & & & 5.91 & & & 17.02 \\
\hline 32 & Tridax procumbens & 10 & 40 & & & 10 & & 60 & 5.56 & 16.67 & & & 5.26 & & 27.49 \\
\hline 33 & Vernonia cineria & & 10 & 20 & 20 & & & 50 & & 4.20 & 11.76 & 11.76 & & & 27.72 \\
\hline 34 & Vetiveria nigrinata & & & 10 & & & & 10 & & & 5.88 & & & & 5.88 \\
\hline 35 & Zornia glochidiata & & & & & & 10 & 10 & & & & & & 6.67 & 6.67 \\
\hline
\end{tabular}


Table 5. Importance value index for herbs identified at Kanawa Forest Reserve (KFR) Gombe State, Nigeria.

\begin{tabular}{|c|c|c|c|c|c|c|c|c|}
\hline & \multicolumn{8}{|c|}{ Importance value index (\%) } \\
\hline & & & Site & & & & & \\
\hline S/No & Species & 1 & 11 & 111 & $1 \mathrm{~V}$ & $\mathrm{~V}$ & V1 & TOTAL \\
\hline 1 & Acanthospermum hispidium & & & & & & 7.50 & 7.50 \\
\hline 2 & Alysicarpus vaginalis & & & & & 5.13 & 7.50 & 12.63 \\
\hline 3 & Andropogan gayanus & & & & & 8.18 & 10.42 & 18.60 \\
\hline 4 & Boerhavia diffusa & & & & & 5.96 & 7.08 & 13.04 \\
\hline 5 & Cenchrus biflorus & & & & & 7.63 & 8.33 & 15.96 \\
\hline 6 & Chamaecrista rotundifolia & & & & & 10.68 & 7.50 & 18.18 \\
\hline 7 & Chloris pilosa & 6.94 & 5.83 & & & 10.68 & & 23.45 \\
\hline 8 & Cleome viscosa & & & & 12.13 & & & 12.13 \\
\hline 9 & Commelina erecta & & 13.75 & & & 6.38 & 7.50 & 27.63 \\
\hline 10 & Cyperus sphacelatus & & 10.72 & 7.68 & 12.13 & & & 30.53 \\
\hline 11 & Dactyloctenium aegyptium & & & & & 12.08 & 7.08 & 19.16 \\
\hline 12 & Digitaria gayana & & & & 10.88 & & & 10.88 \\
\hline 13 & Digitaria horizontalis & 5.28 & & 7.11 & & & & 12.39 \\
\hline 14 & Eragrostis ciliaris & & & 7.11 & & & 12.08 & 19.19 \\
\hline 15 & Eragrostis tremula & & & 7.11 & & & 7.50 & 14.61 \\
\hline 16 & Euphorbia hirta & 14.58 & 7.08 & & & 7.21 & & 28.87 \\
\hline 17 & Fimbristylis ferruginea & & & 14.22 & & & & 14.22 \\
\hline 18 & Fimbristylis meliacea & & & 14.22 & & & & 14.22 \\
\hline 19 & Hyptis suaveolens & 10.83 & 14.71 & & & & & 25.54 \\
\hline 20 & Kyllinga tenuifolia & & 10.42 & 7.11 & 19.26 & & & 36.79 \\
\hline 21 & Nelsonia canescens & & & & & 10.68 & & 10.68 \\
\hline 22 & Ludwigia hyssopifolia & 6.94 & & 10.88 & & & & 17.82 \\
\hline 23 & Oldenlandia corymbosa & 10.14 & & & & & & 10.14 \\
\hline 24 & Pennisetum pedicellatum & & & & & 4.30 & & 4.30 \\
\hline 25 & Physalis angulata & 6.94 & & & & & & 6.94 \\
\hline 26 & Portulaca oleraceae & & & & 12.13 & & & 12.13 \\
\hline 27 & Polygonum senegalense & & & & & 3.88 & & 3.88 \\
\hline 28 & Scleria verrucosa & & & 3.63 & & & & 3.63 \\
\hline 29 & Spermacose verticillata & & & 5.44 & & & 11.67 & 17.11 \\
\hline 30 & Tribulus terrestris & 15.58 & & & 7.94 & & & 25.52 \\
\hline 31 & Tridax procumbens & 6.94 & 14.58 & & & 7.22 & & 28.74 \\
\hline 32 & Typha domingensis & 15.83 & 14.58 & & 13.40 & & & 43.81 \\
\hline 33 & Vernonia cineria & & 8.33 & 10.47 & 12.13 & & & 30.93 \\
\hline 34 & Vetiveria nigrinata & & & 5.02 & & & & 5.02 \\
\hline 35 & Zornia glochidiata & & & & & & 5.83 & 5.83 \\
\hline
\end{tabular}

Table 6. Association, similarity and correlation between sites for herbaceous species at Kanawa Forest Reserve (KFR), Gombe State, Nigeria.

\begin{tabular}{llllll}
\hline Site & Chi-square & Correlation & ad/bc & Sx & Sr \\
\hline Site1/11 & 0.064815 & -0.043033 & - & 34.93519 & 1.043033 \\
Site1/111 & 1.268116 & 0.190347 & - & 33.73188 & 1.190347 \\
Site1/1V & 1.495726 & 0.206725 & + & 33.50427 & 0.793275 \\
Site1/V & 7.304348 & -0.456832 & - & 27.69565 & 1.456832 \\
Site1/V1 & 0.305944 & -0.093495 & - & 34.69406 & 1.093495 \\
Site11/111 & 0.396873 & -0.106486 & - & 34.60313 & 1.106486 \\
Site11/1V & 3.201963 & 0.302464 & + & 31.79804 & 0.697536 \\
Site11/V & 5.410628 & -0.393179 & - & 29.58937 & 1.393179 \\
Site11/V1 & 6.127946 & -0.418431 & - & 28.87205 & 1.418431 \\
Site111/1V & 0.782547 & -0.149528 & - & 34.21745 & 1.149528 \\
Site 111/V & 1.752653 & -0.223776 & - & 33.24735 & 1.223776 \\
Site 111/V1 & 10.79051 & -0.555248 & - & 24.20949 & 1.555248 \\
Site 1V/V & 2.887944 & -0.287250 & - & 32.11206 & 1.28725 \\
Site 1V/V1 & 1.155266 & -0.181680 & - & 33.84473 & 1.18168 \\
Site V/V1 & 3.512149 & 0.316776 & + & 31.48785 & 0.683224 \\
\hline
\end{tabular}




\section{Conclusion}

Kanawa Forest Reserve is dominated by the following herb species: Cyperus sphacelatus-Hyptis suaveolens-Typha domingensis complex. The presence of Typha being an invasive herb species could also be a threat to the native species within the reserve. In order to protect the forest reserve from further encroachment from human activies such as harvesting the herbs for medicinal purposes, and animals foraging on the grasses, the reserve need to be fenced and additional guards be obtained. It was also concluded that the species with the lowest importance value indices were:Pennisetum pedicellatum, Polygonum senegalense, Vetiveria nigrinata, Zornia glochidiata. These plants therefore require more efforts on conservation.

\section{References}

[1] H.M. Abba; F.B.J. Sawa; A.M. Gani . and S. D. Abdul (2013). Study of Kanawa Forest Reserve (KFR). Soil analysis. Unpublished field work for Ph.D thesis.

[2] Abdullahi, M.B (2010). Phytosociological Studies and Community Rural ApppraisalTowards Biodiversity Conservation in Yankari Game Reserve, Bauchi State, Nigeria . An unpublished Ph.D Thesis. Abubakar Tafawa Balewa University, Bauchi, Nigeria, pp 99 .

[3] Abdullahi M.B (2011). An investigation into the Herbaceous plant formations Of Yankari Game Reserve Bauchi, Nigeria. Botany Research Journal 4(3) pp 29-34.

[4] Abdullahi, M.B and Sanusi S.S (2006). A phytosociological survey of the herbaceous Vegetation of the Gaji flood Plains.Yankari National Park, Bauchi.Nigerian Journal of Botany, 19:pp 61-67.

[5] Abdullahi, M.B, S.S Sanusi, S.D, Abdul and F.B.J. Sawa (2009). An assessment of the herbaceous species vegetation of yankari game reserve, Bauchi, Nigeria. American Eurasian Journal of Agricultural and Environmental Science 6:pp20-25.

[6] Ahmad, S. S. and Ehsan, H. (2012) Analyzing the herbaceous flora of LohiBher Wildlife Park under variable environmental stress. Pak. J. Bot., 44(1):pp11-14.

[7] Akobundu, I.O. and C.W Agyakwa. (1998). A Hand Book of West African Weeds.International Institute of Tropical Agriculture, IITA, Ibadan.pp 1-.557.

[8] Atiku, M, and Bello, A.G (2011). Diversity of herbaceous plants in Wassaniya Forest Reserve of Sokoto State, Nigeria.Forestry Association of Nigeria, Conference paper.pp 438-443

[9] Blair, R.A (1976). A Field Key to the Common Genera of Nigerian Grasses.Part 1 and 2. University Press Ibadan.pp76.

[10] Broekhuyse, J.T and A.M. Allen (1984). Farming Systems Research on the Northern Mossi Plateau.Journal of Human biology Organs.47:pp 330-342.
[11] Campbell, DG (1994). Scale and pattern of community structure in Amazonian rainforest in Edwaeds P J. May RM.Web NR (eds ) Larger scale ecology and conservation biology. Blackwell, Oxford.

[12] Causton, DR (1988). Introduction to Vegetation Analysis: Principles, Practice and Interpretation. Unwin Hyman Ltd, London.pp 342.

[13] Cottam, G and Curtis J.T (1956). The use of distance measurements in phytosociological sampling.Ecology 37(3)pp460.

[14] Curtis, J.T and McIntosh, R.P (1951). An Upland continuum in the Praire- Forest Border region of Wisconsin, Ecology, $32, p p 476-496$.

[15] Curtis, JT (1957). The vegetation of Winsconsin: An ordination of plant communities.Uniersity of Wisconsin press Madison,Wisconsin.pp657

[16] Dallmeier, F. (Ed.). (1992). Long-term monitoring of biological diversity in Tropical Digest 11 .UNESCO, Paris.

[17] Department of Environment and resource management (2010). Fitzroy Basin Draft Water Resource Plan environmental assessment: Stage 2 assessment report, DERM, Brisbane.

[18] Dix, R. L (1971). An application of the point-centered quarter method to the samplingof grassland vegetation. Journal of Range Management. 14:63-69pp

[19] Fenner, M. (1985). Seed Ecology. Chapman and Hall, London, $151 \mathrm{pp}$.

[20] Gilliam, F. S. (2007). Ecological Significance of the Herbaceous Layer in Temperate Forest Ecosystems; Biosceince.57(10) 845 - 858pp. 2007 American Institute of Biological Sceinces.http:// dx.doi.org/ 10.164//B571007 http:// www.bioone.org/doi/full/10.1641B5710007

[21] Gombe Native Authority (1945). Preliminary report on proposed Gombe Native Authority Forest reserve . No 4 of the former Gombe Native Authority, Northern Nigeria.Now Gombe State, Nigeria.pp 1-10.

[22] Harper, J. L (1977). Population Biology of Plants, Academic Press: New York-London,

[23] Hornby, A. S. (2001). Oxford Advanced Learners Dictionary .6th Edition . Oxford University Press, Oxford, New York.pp580.

[24] Hutchinson J and Dalzeil J.M. (1954-1972). Flora of West Tropical Africa.Vol.1 - 11l . 2nd Rev.Edition. Millbank, London.

[25] Iwara A.LOffiong,R.A, Nar, G.N.Ogundele,F.O ( 2014). An assessment of Herbaceous Species Diversity, Density, Cover in Agoi Ekpo, Cross River State, Nigeria.International Journal of Biological Sciences. 01( 01) : 21-29.

[26] Jennings, M.D., Faber-Langendoen, D., Loucks, O. L., Peet, R. K. and Roberts, D. (2009) Standards for associations and alliances of theU.S. National Vegetation Classification. Ecological Monographs, 79 (2):pp 173-199.

[27] Kumar, A., B. G Marcot and A Saxena (2006).Tree speciesDiversity and distribution patterns in tropical forests of Garo Hills.Current Science. 91 (10); pp11-25 
[28] Lowe, J and Stanfeild, D.P (1974).The Flora of Nigerian Sedges (Family Cyperaceae).University press. Ibadan. Nigeria.pp 140-185.

[29] Milton, S.J. and Dean, W.R.J. (2001). Disturbance, drought and dynamics of desert dune grassland, South Africa.Plant Ecology.150:pp 37-51.

[30] Misra, R (1968). Ecology work Book.Oxford and IBH Publishing Co.Calcutta.244 pp.of grassland vegetation.Journal of Range Management.14:pp63-69

[31] Olff, H. and Ritchie, M.E (1998). Effects of herbivore on grassland plant diversity, Trends in Ecology and Evolution 13,pp 261-265

[32] Richard, A. G., Emmanuel, K. B., Canisius J. K., Emmanuel B.M., Almas, M. K and Philipina F. S (2011). Species Composition, Richness and Diversity in Mimbo Woodland of Bereku Forest Reserve, Tanzania. Journal ofBiodiversity, 2(1): (2011) pp1-7.

[33] Rosenzweig, M. (1995). Species diversity in space and time. Cambridge University Press, Cambridge.171pp

[34] Sabogal, C. (1992). Regeneration of tropical dry forests in Central America, with examples from Nicaragua. J Veg Sci

\section{$3: 407-416 \mathrm{pp}$}

[35] Samaila, M (2011). The geology of Kanawa and its environs, part of Gombe sheet 152 NE, Gombe State, Nigeria.An unpublished B.Sc thesis. Department of geology, Gombe State University, Gombe, Nigeria.pp 47.

[36] Shannon, C.E. (1948). A mathematical theory of communication.Bell System Technical Journal 27: 379-423 and pp623-656.

[37] Simpson E. H (1949). Measurement of diversity. Nature, 163, $688 \mathrm{pp}$

[38] Sobuj, N.A and Rahman.M (2011). Assessment of plant diversity in Khadimnagar National Park of Bangladesh.Department of Forestry and Environmental Science, School of Agriculture and Mineral Sciences, Shah Jalal University of Science and Technology, Sylhet 3114, Bangladesh. International Journal of Environmental Sciences. 2 .No.1. pp 91.

[39] Vierich, H.I.D and Stoop, W.A (1990). Changes in West African Savanna Agriculture in Response to Growing Population and Continuing Low Rainfall.Agric. Ecosys. and Environ. 31:pp115- 132. 